\title{
Social skills, coping, resilience and problem-solving in psychology university students
}

\section{Habilidades sociales, coping, resiliencia y resolución de problemas en estudiantes de psicología}

\author{
Zeimara de Almeida Santos ${ }^{\mathrm{a},{ }^{*}}$, Adriana Benevides Soares ${ }^{\mathrm{b}, \mathrm{c}}$ \\ ${ }^{a}$ Universidade Salgado de Oliveira, Brasil \\ bUniversidade Estadual do Rio de Janeiro, Brasil \\ 'Universidade Salgado de Oliveira, Brasil
}

\begin{abstract}
This work aimed to identify the relationship between Resilience, Coping, Social Skills and Problem-Solving, and compare said constructs between psychology students and students from other areas of human sciences. Eight hundred sixteen (816) university students from public and private institutions in the state of Rio de Janeiro whose age ranged from 17 to 44 years participated in this study. The research instruments were: Social Skills Inventory Scale, Problem-Focused Coping Scale, Resilience Scale for Adults, and Problem-Solving Skills Scale. The results showed differences between the groups of students regarding social skills deficits, and a positive correlation between the Problem-Focused Coping Scale and the Problem-Solving Skills Scale. This data contributes to the initiative of adjusting the educational program for the purpose of developing the social interaction skills involved and required in the training of future psychologists.
\end{abstract}

Keywords: social skills, university students, psychology, interaction.

Para citar este artículo:

de Almeida, Z., \& Benevides, A. (2018). Social skills, coping, resilience and problem-solving in psychology university students. Liberabit, 24(2), 265-276. https://doi.org/10.24265/liberabit.2018.v24n2.07

\section{Resumen}

Este trabajo buscó identificar la relación entre Resiliencia, Coping, Habilidades Sociales y Resolución de Problemas y comparar los constructos en estudiantes de Psicología con otros estudiantes de otras áreas de las Ciencias Humanas. Participaron 816 estudiantes universitarios de instituciones públicas y privadas del Estado de Río de Janeiro, con edades variando entre 17 y 44 años. Los instrumentos utilizados fueron el Inventario de Habilidades Sociales, la Escala Modos de Afrontamiento de Problemas, la Escala de Resiliencia para Adultos y la Escala de Habilidades para la Resolución de Problemas. Los resultados obtenidos revelaron diferencias entre los grupos de estudiantes en lo que se refiere a los déficit de HS y la correlación positiva entre la Escala de Afrontamiento y la Escala de Habilidades para la Resolución de Problemas. Estos datos contribuyen a la iniciativa de ajuste de la programación de enseñanza orientada al desarrollo de habilidades de interacción social involucradas y requeridas en la formación del futuro psicólogo.

Palabras clave: habilidades sociales, universitarios, psicología, interacción.

Este es un artículo Open Access bajo la licencia Creative Commons Atribución-NoComercial-CompartirIgual 4.0

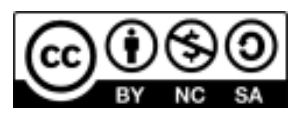




\section{Introduction}

When university students start their higher-level academic life, they are faced with several new tasks they have to cope with, such as the need to be more autonomous, in order to solve problems that they are not yet accustomed to, and to deal with new interpersonal relationships. Usually, this results in having difficulties when trying to manage all these demands. The academic environment in which knowledge is built is a proper context for the development of the educational autonomy aimed at solving new cognitive and academic demands (Ribeiro \& Bolsoni-Silva, 2011; Yamamoto, da Rocha Falcão, $\&$ de Sousa Seixas, 2011). This same context requires that students meet schedules, show up to classes, organize internships, take exams, and face other demands which can be challenging because they will need to have appropriate relationships and act in a responsible way to solve their problems/conflicts during their training. They should acquire all those skills to master the necessary demands of each area of knowledge, especially for the psychology program subjects (Beiter et al., 2015).

Many gaps have been reported in the training of psychology students (Mourão \& Abbad, 2016). Universities and other academic institutions must be prepared and efforts must be taken by them to overcome this situation. Therefore, it is necessary to know psychology students' psychosocial characteristics, so that psycho-educative or remedial strategies can be proposed to act in accordance with their needs. Knowing how to deal with each other, and how to solve, face and overcome their problems can be a way to improve students' assistance and training programs.

Even though the psychology program is one that privileges social interactions, it has been observed that the program prepares students only with generic skills, with a strong technical/mechanic bias compromising a proper work performance (Gondim, Bastos, \& Peixoto, 2010), and neglects social-emotional skills as a foundation for students' personal development (Del
Prette \& Del Prette, 2003; Leme, Del Prette, Koller, \& Del Prette, 2016). Social-emotional development is based on reflective/intentional learning and socioemotional competencies linked to the curricular content as synonym of success in personal, academic and professional life (Braga, Pereira, \& Simões, 2016). Although the expectation is that students, as future professionals, respond positively to the interactive demands of their performance after their academic training, they are faced with lack of preparation to adequately deal with the processes of interpersonal interaction (Pasqualotto \& Lohr, 2015). When interpersonal interaction is not socially competent, deficits in the practice of the future psychologist are visible (Del Prette, Del Prette, \& Barreto, 1999). In general, some studies (Mourão \& Abbad, 2016; Lins et al., 2015) have shown that the university training of psychology students does not present any differences compared to the training of students from other branches of study. Data collected by Pereira et al. (2014) from a sample of 69 students from two private universities in Rio Grande do Sul, Brazil, indicated that $43.5 \%$ of the students showed deficits in social skills, presenting low scores in selfaffirmation of positive affect and self-esteem, confrontation and self-assertion with risk. These results are confirmed by the study of Bolsoni-Silva et al. (2010) who verified, with a sample of 85 psychology students, that difficulties in social interactions relate to the adaptation of university students. The study results indicated differences between both sexes and between the periods of study, namely, greater differences in beginners, demonstrating the necessity of interventions at this level of training.

Considering social skills as a set of social behaviors that can contribute to a socially competent performance in interpersonal tasks (Del Prette \& Del Prette, 2017), we would like to highlight some empirical studies that seek to identify how social skills can help students to cope with interpersonal situations in everyday life (Masten, 2014; Tavares, Couto, \& Silva, 2012), to use coping strategies to be more socially competent (Oliveira, Dias, \& Piccoloto, 2013), 
and also to get better problem-solving skills (Del Prette \& Del Prette, 2013). Thus, it can be concluded that a sufficient social-skills repertoire has shown to be not only a protective factor against the challenges faced by graduates when dealing with complex demands in the academic routine, but also a contribution to professional training (Soares \& Del Prette, 2015).

In addition to relational skills, the academic context is also a challenge for new students to cope with and solve problems (D’Zurilla \& Nezu, 2010). On this matter, problem-solving requires the right choice of coping strategies, meaning that problem-solving is a process which enables students to implement coping strategies to deal with everyday demands, and highlights how social skills are critical for university students to better experience their interpersonal relations. The study performed by Hisch, Balem, Almeida, TomaschewskiBarlem, Figueira and Lunardi (2015) with a sample of 146 university students indicated that students that are more satisfied with the program deal more affirmatively with difficult situations of the academic routine by using more positive coping strategies, seeking to get something good out of the situation that was initially considered complex.

Overall, coping strategies, problem-solving (Ramos \& Carvalho, 2007) and humor (Oguz-Duran \& Yüksel, 2010) were associated with lower levels of stress at the university. In a recent study on coping conducted in 412 university students, Carlotto, Teixeira and Dias (2015) concluded that the strategies focused on emotions were negatively correlated with the process of academic adaptation. They also concluded that the strategy based on social support correlated positively with the process of academic adaptation, thus indicating that the search for support may suggest an inability to deal with individual stressors. On the other hand, the study carried out by Oliveira, Carlotto, Vasconcelos and Dias (2014) identified that coping strategies based on problem-solving, confrontation and social support may be related to a better adaptation to the demands at the university.
Data collected by Lizarraga (2010) highlighted that using decision-making abilities stimulates mental triggers involved in the analysis of information, the generation of alternatives/strategies for problem-solving, and the election of the best alternative (creative/critical thinking). In this context, solving problems/conflicts involves forms of cognitive/behavioral efforts to regulate adverse situations and to overcome problems. Possessing proficiency to deal with adversity and problem-solving tasks is considered critical to have resilient attitudes. Therefore, resiliency is the ability of individuals to use available personal and contextual resources to manage adversities (Juliano \& Yunes, 2014).

To overcome adversity and be resilient, students need to dynamically perceive themselves in interaction with their socio-cultural environment, and to organize themselves in response to changes in their ecological context and their own organic development (Fletcher \& Sarkar, 2013). Some studies have dealt with this topic. The study conducted by Montes, Lupercio and González (2016) with a sample of 141 Mexican public university students showed that resilience to overcome academic and interpersonal problems is common in university students and is independent of the field of study. The study by Oguz-Duran and Yüksel (2010) investigated how undergraduates face adverse situations in higher education, and found that students who used cognitive resources were better able to adapt and resolve their conflicts. The authors suggest that knowing psychosocial characteristics in undergraduates can help universities to develop preventive strategies to improve these students' problem-solving social capacity.

Although literature shows differences between certain abilities in psychology students' training, the present study proposes the joint use of these variables as an option for conducting a panoramic analysis, and understand the relationship between psychology students and other humanities programs. Considering that psychology students' training is focused on professional performance and research, social skills can help students to manage everyday interpersonal 
situations, and facilitate their commitment to defend citizenship and human dignity. It should be noted that the relationship of these variables can indicate which coping strategies can be based on the problem-solving used by these individuals. In addition, confronting the acquisition of important social skills required in the development of socially desired repertoires can maximize interactions during the training. Therefore, this study aimed to identify the relationship between Social Skills and Problem-Solving, Coping and Resilience, and to compare the variables between psychology students and students from other areas of human sciences. It was hypothesized that there is a positive relationship between the factors of the variables Social Skills, Problem-Solving, Coping and Resilience in psychology students, and that they show higher scores on the presented variables than other university students.

\section{Method}

\section{Participants}

Eight hundred sixteen (816) university students participated in this study, out of which 409 were psychology students and 407 human sciences students from public (9.2\%) and private institutions (90.8\%) from the state of Rio de Janeiro. The age spectrum ranged from 18 to 34 years of age $(M=25.46 ; D P=$ 4.89), 556 students (68.14\%) were females and 260 males (31.86\%). Participants belonged to social class A $(\mathrm{N}=136)(16.67 \%), \mathrm{B} 1(\mathrm{~N}=244)(29.90 \%), \mathrm{B} 2$ $(\mathrm{N}=235), \mathrm{C} 2(\mathrm{~N}=14)(1.72 \%)$ and $\mathrm{D} / \mathrm{E}$, and were all at least in the fourth period of their respective programs.

\section{Instruments}

Social Skills Inventory Scale (SSIS) (Del Prette \& Del Prette, 2001) is a self-reported instrument composed of 38 items that describe social situations in various contexts. It is a Brazilian instrument which has an internal consistency of .75. The instrument consists of five factors: 1 ) Confrontation with Risk (11 items, $\alpha=0.96)$, 2) Self-Affirmation in the
Expression of Positive Affect (7 items, $\alpha=.86$ ), 3) Conversation and Social Development (7 items, $\alpha=$ $.81)$, 4) Self-Exposure to Strangers or New Situations (4 items, $\alpha=.75$ ), and 5) Self-Control of Aggressiveness to Adverse Situations (3 items, $\alpha=$ $.74)$.

Problem-Focused Coping Scale (PFCS) (Vitaliano, Russo, Carr, Maiuro, \& Becker, 1985; adapted to Portuguese by Gimenes \& Queiroz, 1997; and validated for the Brazilian population by Seidl, Trocoli, \& Zannon, 2001) is a self-reported instrument with 45 items distributed in four factors assessing the thoughts and actions a subject uses to deal with external and internal demands in a stressful situation: 1) Problem Focusing (18 items, $\alpha=.84$ ), 2) Emotion Focusing (15 items, $\alpha=0.81$ ), 3) Social Support Search (5 items, $\alpha=.70$ ), and 4) Search for Religious Practices (7 items, $\alpha=0.74$ ). Responses are given using the 5-point Likert scale (ranging from $1=$ «I never do this» to $5=$ «I always do this»). The scores are obtained by the arithmetic mean: the higher the score, the higher the frequency of use of the coping strategy.

Resilience Scale for Adults (RSA) (Hjemdal et al., 2006; adapted to and validated for Portuguese by Hjemdal, Roazzi, Dias, Roazzi, \& Vikan, 2009) is an instrument that contains 33 items structured on a seven-point scale in a semantic differential format. Each item is organized as a continuum, and its opposites present positive and negative response alternatives. 1) Self-Perception (6 items, $\alpha=.74$ ), 2) Planned Future (4 items, $\alpha=.72$ ), 3) Social Competence (6 items, $\alpha=.67$ ), 4) Structured Style (4 items, $\alpha=.51$ ), 5) Family Cohesion (6 items, $\alpha=$ .75), and 6) Social Resources (7 items, $\alpha=.73$ )

Problem-Solving Skills Scale (PSSS) (D’Zurilla \& Nezu, 1990; adapted by Sá, 2005) is an instrument that assesses the ability to solve problems according to the behavioral and cognitive abilities of the subject. It consists of 40 items distributed equally in five dimensions: 1) Problem Formation (10 items, $\alpha=.76$ ), 
2) Generation of Alternatives (10 items, $\alpha=.44)$, 3) Decision-Making (10 items, $\alpha=.64)$, and 4) Solutions Verification (10 items, $\alpha=.57$ ). The scale scores range from zero to 160 , and the scale has an internal consistency of .92. The eleven items have reverse pooled answer options.

\section{Procedures and statistical analysis}

All participating students signed a Free and Informed Consent Term (TCLE). The project was approved by the University Ethics Committee, and the participants' voluntary consent was obtained through the signing of an Informed Consent Form. The questionnaires were administered during the students' free time in the following order: Social Skills Inventory Scale, Problem-Focused Coping Scale, Resilience Scale for Adults, and Problem-Solving Skills Scale. To compare the mean differences between the groups, the Student's t-test was applied in independent samples assuming the normal distribution of the samples. For all the t-test analyses, re-sampling procedures (bootstrapping, 1000 re-sampling, with 99\% confidence interval) were implemented to obtain greater reliability of the results, correct possible sample deviations from normality, and present a confidence interval of 99\% for mean differences (Haukoos \& Lewis, 2005). The effect size was calculated using Cohen's D test. In order to verify the correlation between the factors of the studied constructs, we used the parametric statistical correlation of Pearson's linear coefficient, since it indicates the best level of correlation between the variables (significance test) and the probabilistic distribution of the value that occurs through sampling error. Pearson's linear coefficient, which summarizes the degree of correlation between two variables, serves to describe the magnitude and direction of the correlation between the variables under study. Therefore, it was taken into account that correlation coefficients usually range from +1.00 (perfect direct correlation), go through 0.00 (absence of correlation) to -1.00 (perfect inverse correlation) (Dancey \& Reidy, 2013).

\section{Results}

The Pearson Correlation test was used to answer the hypothesis which states that there is a correlation between the factors of the constructs Social Skills, ProblemSolving, Confrontation and Resilience in psychology students. The collected data confirmed this hypothesis, since it demonstrated positive and weak correlations in the following factors: Confrontation with Risk of the Social Skills Inventory Scale; Social Competence (ability to initiate verbal contacts and be flexible in social interactions, create new friendships) of the Resilience Scale for Adults; Self-Affirmation in the Expression of Positive Affect (expression of positive affections and affirmation of self-esteem) of the Social Skills Inventory Scale; and Problem Focusing (positive reaction to face a stressful situation with the aim of solving it) of the Problem-Focused Coping Scale. The same was noted between the factor Self-Affirmation in the Expression of Positive Affect of the Social Skills Inventory Scale and the factor Generation of Alternatives of the ProblemSolving Skills Scale; and between the factor Planned Future (optimistic vision of the future itself, certainty that it can be successful, and ability to plan and establish clear and achievable goals) of the Resilience Scale for Adults and the factor Problem Focusing of the Problem-Focused Coping Scale. The correlation between the ProblemSolving Skills Scale and the Resilience Scale for Adults was also positive and weak, as well as between the factor Social Support Search (information search, counseling and reception to face the problem) of the ProblemFocused Coping Scale, the factor Self-Perception (selfconfidence, self-efficacy, and positive and realistic selfvision) of the Resilience Scale for Adults, and the factor Problem Formation (rationality) of the Problem-Solving Skills Scale. In relation to the factor Problem Focusing of the Problem-Focused Coping Scale and the factor Problem Formation of the Problem-Solving Skills Scale, and to the total scores, the correlation was also positive and weak. Finally, the correlation was positive and moderate between the Problem-Focused Coping Scale and the factor Problem Formation of the Problem-Solving Skills Scale. These results are displayed in Table 1. 


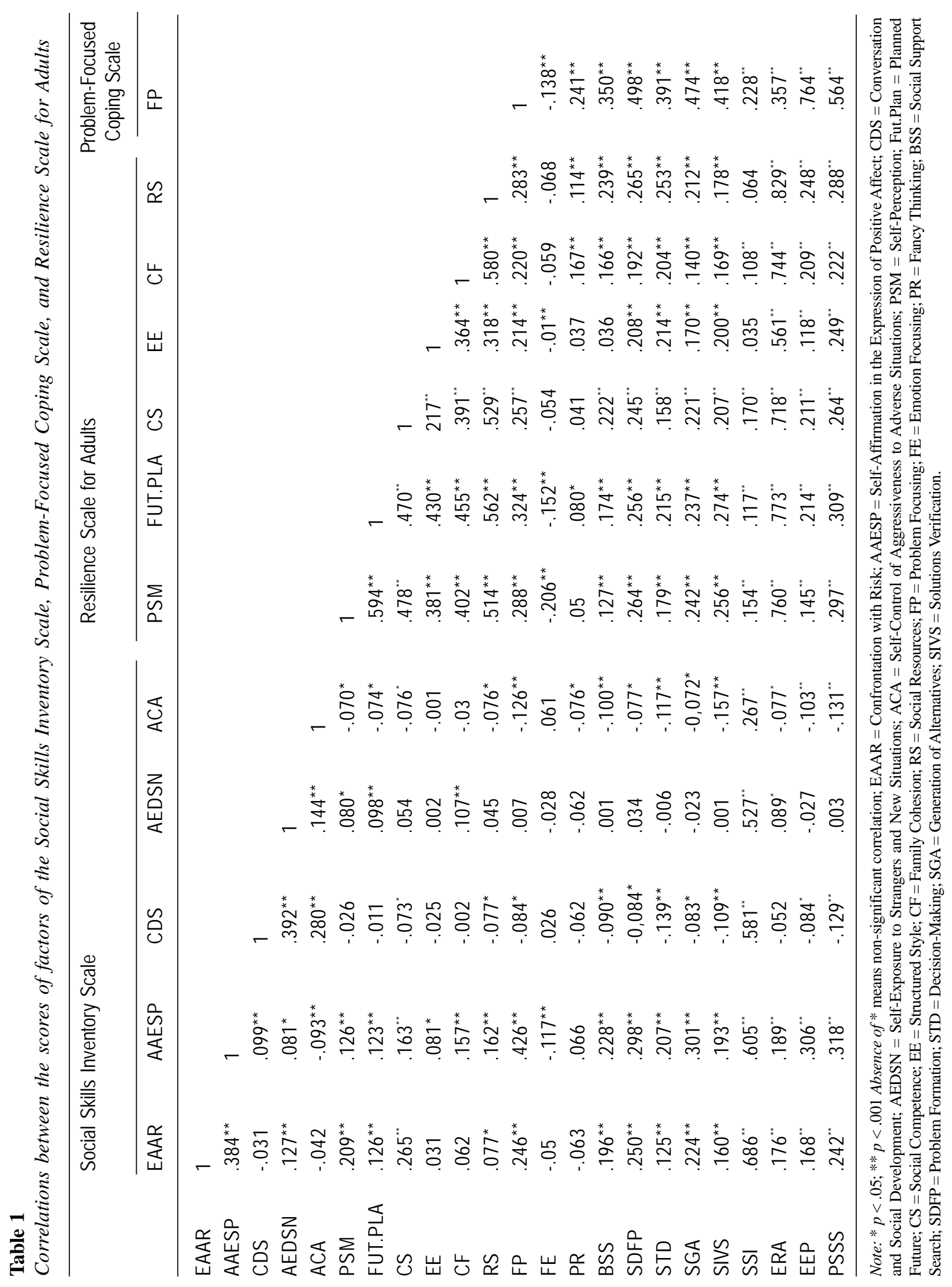


To answer the hypothesis which states that there is a difference between students from other areas of the human sciences and psychology students, the Student's t-test was used to compare the groups, and later the Cohen d-test was performed to calculate the effect size in the Problem-Solving Skills Scale, Problem-Focused Coping Scale, Resilience Scale for Adults, and Social Skills Inventory Scale. The results are displayed in Table 2.

\section{Discussion}

The variables presented a correlation in almost all their factors, and the discussion favored the associations of greater magnitude. According to the objective of identifying the association between the constructs, the results showed that the factor Confrontation with Risk of the Social Skills Inventory Scale (which refers to situations of relationship in which assertiveness is affirmed with the potential risk of an undesirable reaction) had a very positive correlation with the factor Social Competence of the Resilience Scale for Adults. In this respect, data shows that the more the university deals with demands that offer interpersonal risk, the more resilient they are (Fletcher \& Sarkar, 2013). This may demonstrate that the proper use of the ability of students to socially position themselves facilitates their flexibility in interactions of their social life. This result corroborates Pasqualotto and Lohr's study (2015) of 86 graduate students from a public higher-education institution in the state of Paraná, which evaluated the repertoire of social skills and the degree of resilience of these students from different programs, and identified the appropriate predominant repertoire of social skills and resilience of the individuals who chose undergraduate programs. This data may be an important indicator, since graduates with the highest social skills index seek teaching, investing in the development of these skills, and consequently in the quality of education.

Regarding the correlation between the factors SelfAffirmation in the Expression of Positive Affect of the Social Skills Inventory Scale, Problem Focusing of the Problem-Focused Coping Scale and Generation of Alternatives of the Problem-Solving Skills Scale, the more the university recognizes situations in which the expression of positive opinions can facilitate students' interpersonal relationship, better their perception of reality and investment in the attempt to use practical rules/creative solutions for the problems, and their adaptation to university life. In this respect, Gomes and Soares (2013) emphasize that undergraduate students face many academic and personal difficulties, and need to learn how to solve conflicting situations related to the university environment. According to Haward (2005), the ability to interpret challenges rationally, in most cases, can result in the use of adequate personal, social and institutional resources for decision-making.

Concerning the relationship between the factor Planned Future of the Resilience Scale for Adults and the factor Problem Focusing of the Problem-Focused Coping Scale, the more students recognize their uncertain future, stronger is their desire to fit in and to adapt. When students are focused on a problem, they usually use negotiation strategies to solve/modify a situation or an interpersonal conflict with the help of others (Santos, 2016; Lizarraga, 2010). Despite the context of adversity and intense confrontation, these students may find social expectations (linked with the educational institution, and relational and academic adjustment) related to continuing their studies and planning their professional practice (Braga, Pereira, \& Simões, 2016). This result indicates that resilience is an important characteristic in the healthy adaptation of most students in the university (Masten, 2014; Montes, Lupercio, \& González, 2016), because the dynamics of higher education consists of social (difficulty in interpersonal interaction), personal (combination with family responsibilities) and academic (autonomous development of learning processes) requirements that are not easy tasks (Fernandes, 2011).

Regarding the relationship between the factor Problem Formation of the Problem-Solving Skills Scale and the factors Self-Perception and Social 


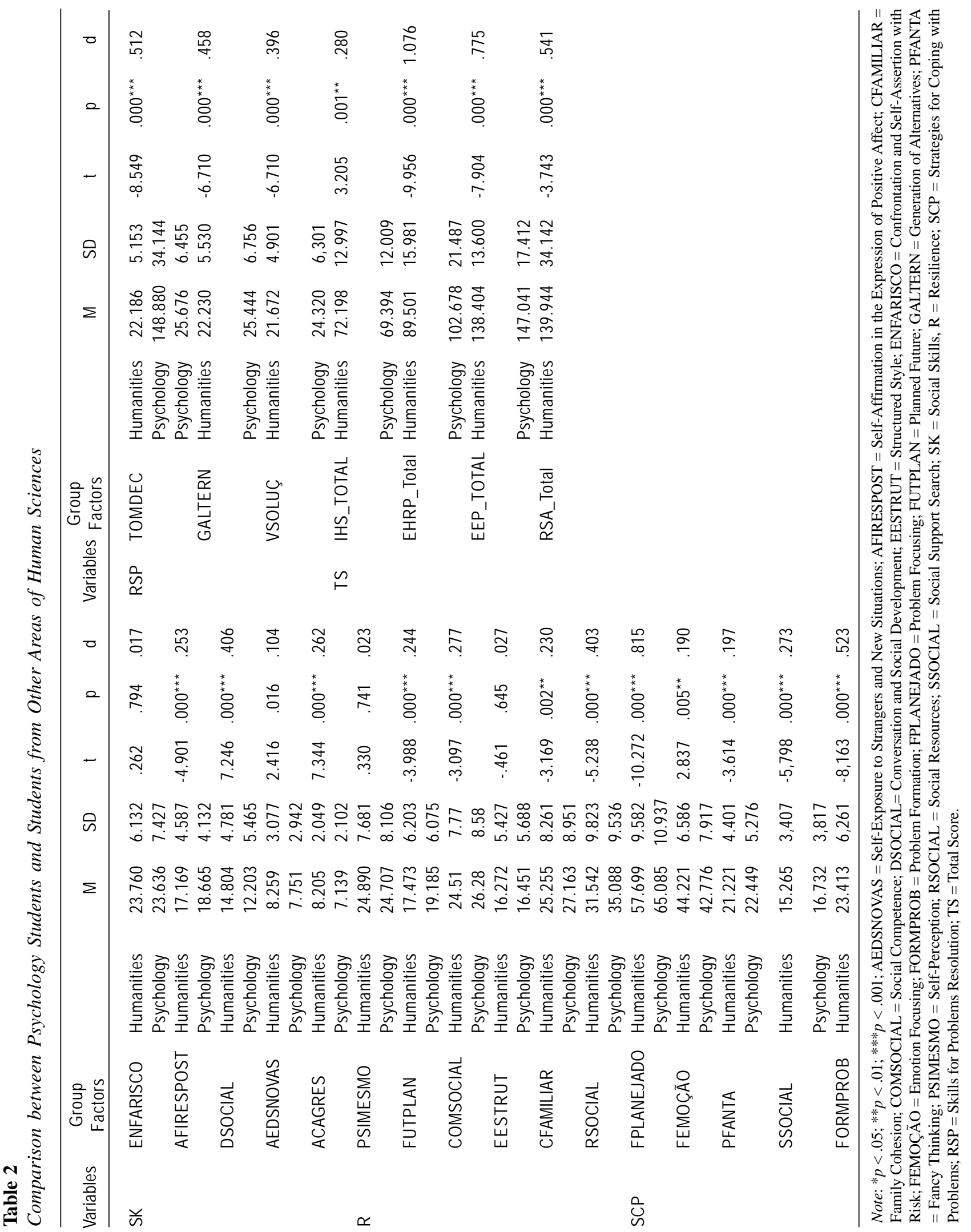


Competence of the Resilience Scale for Adults, it was shown that the more students identify a situation of conflict in the academic field, the greater their need to recover from critical situations, as well as to capture and overcome the stressors that they experience during their training, as long as they also have the support of other people. In other words, students relate positive experiences that lead to feelings of self-esteem and autonomy, so that they can deal with changes to solve problems. Thus, students build personal resources that provide greater satisfaction to deal with adversities (Juliano \& Yunes, 2014; Oliveira, Dias, \& Piccoloto, 2013). All the constructs of this study are related: they emphasize that students with high scores on problemsolving skills also have high scores on the scale of coping strategies. According to Z. Del Prette and Del Prette (2013), problem-solving skills can help students to cope with conflicts, assist them in decision-making, and help them with relational difficulties. The ability to solve conflicts together with coping strategies are cognitive processes that deal with the demands of daily academic life, as they involve making efforts, plans and alternative actions with the purpose of solving any situation (Hisch et al., 2015; Oliveira et al., 2001; Ramos \& Carvalho, 2007; Wilhelm \& Zanelli, 2014).

Concerning the comparison with students from other areas of human sciences, the study showed that psychology students present higher scores of Resilience, Coping, Social Skills and Problem-Solving, and lower scores in Conversation and Social Development, Self-Exposure to Strangers or New Situations and Self-Control of Aggressiveness to Adverse Situations of the Social Skills Inventory Scale. This result is disturbing, as future psychologists need these abilities to talk and relate interpersonally in an appropriate manner. Studies on the characterization of psychology students also have similar results (Carneiro \& Teixeira, 2011; Pereira, Wagner, \& Oliveira, 2014). It is assumed that having social skills, especially in Conversation and Social Development and Self-Exposure to Strangers or New Situations, may favor dealing with adversities appropriately (Pereira et al., 2014). This argument, pointed out by Loureiro and Sanches (2006), and Del Prette and Del Prette (2006), states that in order to deal with adversities adequately it is important to develop a good repertoire of social skills.

Considering the size of the effect on the differences between the groups, the findings on total scores show social skills deficits in psychology students compared to the other group of students. These findings suggest that teaching programs aimed at developing social interaction skills are a requirement in the training of future psychologists (Beiter et al., 2015; Yamamoto et al., 2011). Regarding the differences between the groups, it was also found that psychology students use the strategy of problem focusing to face the daily difficulties of individuals, which makes these students more prepared to deal with complex situations. Against the desired result, graduates from other areas of human sciences presented higher scores in strategies of confrontation focused on emotions, which is also worrisome. This strategy may lead them to separate from certain adverse situations and reality, in order to try to manage the emotional tension in a palliative way.

\section{Final Considerations}

This study aimed to identify the relationship between Social Skills, Problem-Solving, Coping and Resilience, and compare the constructs between psychology students and students from other areas of human sciences. The research found that psychology students have higher scores on all factors of the Problem-Solving Skills Scale but lower ones in the Social Skills repertoire. These findings demonstrate the need for support programs, e.g. in-depth training assisted monitoring and evaluation of results in the academic programs of future psychologists, since the profession requires interpersonal relationship skills to be socially competent. The change in the program cannot be reduced only to scientific contents; it also needs to integrate communication skills, argumentation, flexibility and adaptability as important requirements for working and dealing with future clients. 
Some limitations are evident, such as the small number of students from public institutions and the fact that only university students from the metropolitan region of Rio de Janeiro participated. Another limitation was the absence of comparison of coping strategies used in both sexes. In general, we highlight the need for future research that seeks to improve the training quality of professional psychologists.

\section{Conflicts of interest}

The authors declare that there are no (moral, economic, workplace and research) conflict of interests.

\section{Ethical responsibility}

The project proposal was sent to the Ethics Committee of the Salgado de Oliveira University and approved with consubstantial opinions. It was requested by means of a letter of consent/authorization from the teaching institutions. Subsequently, an approach was made to the university students who signed the Free and Informed Consent Form, and answered the Sociodemographic Data Questionnaire to actively participate in the study. This form guarantees total anonymity of research participants and the possibility of withdrawal at any time. The data includes an e-mail address and telephone number in case contact is required. Materials used for data collection will be stored for five years, as recommended by Resolution No. 466 of the National Health Council (CNS) dated December 12, 2012.

We seek to follow the protocol required by the affiliated university regarding the study participants' care. The proposal was approved by the Brazilian platform of the Research Ethics Committee with document number 114919/2017. Researchers masked the sources of participants' identification, protecting them by means of anonymity.

\section{Acknowledgments}

We thank the Coordination of Improvement of Higher Level Personnel for the financial incentive (stock exchange) and the affiliated institution.

\section{References}

Associação Brasileira de Empresas de Pesquisa (ABEP) (2015). Critério Brasil e atualização da distribuição de classes para 2016. Retrieved from http://www. abep.org/criterio-brasil

Beiter, R., Nash, R., McCrady, M., Rhoades, D., Linscomb, M., Clarahan, M., \& Sammut, S. (2015). The prevalence and correlates of depression, anxiety, and stress in a sample of college students. Journal of Affective Disorders, 173, 90-96. doi:10.1016/j.jad.2014.10.054

Bolsoni-Silva, A. T., Loureiro, S. R., Rosa, C. F., \& de Oliveira, M. C. F. A. (2010). Caracterização das habilidades sociais de universitários. Contextos Clínicos, 3(1), 62-75. http://dx.doi.org/10.4013/ctc. 2010.31.07

Braga, M., Pereira, D., \& Simões, M. C. R. (2016). Aprendizagem socioemocional: a intervenção psicomotora em meio escolar para redução de problemas de comportamento e melhoria das competências académicas. Journal of Child \& Adolescent Psychology, 7, 1-2

Carlotto, R. C., Teixeira, M. A. P., \& Dias, A. C. G. (2015). Adaptation to University and Coping among Undergraduate Students. Psico-USF, 20(3), 421-432. http://dx.doi.org/10.1590/1413-82712015200305

Dancey, C. P., \& Reidy, J. (2013). Estatística sem matemática para psicologia. Penso Editora.

D’Zurilla, T. J., \& Nezu, A. M. (2010). Problem-Solving Therapy. Handbook of Cognitive-Behavioral Therapies, 3, 197-225.

Del Prette, A., \& Del Prette, Z. A. P. (2003). No contexto da travessia para o ambiente de trabalho: treinamento de habilidades sociais com universitários. Estudos de Psicologia, 8(3), 413-420. doi: 10.1590/S1413-294 X2003000300008

Pinheiro, M. I. S., Haase, V. G., Del Prette, A., Amarante, C. L. D., \& Del Prette, Z. A. P. (2006). Treinamento de habilidades sociais educativas para pais de crianças com problemas de comportamento. Psicologia: reflexão e crítica, 19(3), 407-414.

Del Prette, Z. A. P., de Oliveira Barreto, S., \& Freitas, L. C. (2011). Habilidades sociais na comorbidade entre dificuldades de aprendizagem e problemas de 
comportamento: Uma avaliação multimodal. Psico, 43(1), 503-510.

Del Prette, A., Del Prette, Z. A., \& Barreto, M. C. M. (1999). Habilidades sociales en la formación profesional del psicólogo: análisis de un programa de intervención. Psicología conductual, 7(1), 27-47.

Del Prette, A., \& Del Prette, Z. (2010). Psicologia das Relações Interpessoais: Vivências para o trabalho em grupo, 8a edição - Petrópolis, RJ. Vozes.

Del Prette, Z. A. P., \& Del Prette, A. (2013). Social Skills Inventory (SSI-Del-Prette): Characteristics and studies in Brazil. In F. L. Osório (Org.), Social anxiety disorders: From theory to practice (pp. 4962). Nova Iorque: Nova Science Publishers.

Gimenes, M. D. G., \& Queiroz, B. (1997). As diferentes fases de enfrentamento durante o primeiro ano após a mastectomia. A mulher e o câncer, 171-195.

Gondim, S. M. G., Bastos, A. V. B., \& Peixoto, L. S. A. (2010). Áreas de atuação, atividades e abordagens teóricas do psicólogo brasileiro. In A. V. B. Bastos \& S. M. G. Gondim (Orgs.), O trabalho do psicólogo no Brasil (pp. 174-199). Porto Alegre: Artmed.

Haukoos, J. S., \& Lewis, R. J. (2005). Advanced statistics: bootstrapping confidence intervals for statistics with «difficult» distributions. Academic emergency medicine, 12(4), 360-365.

Hirsch, C. D., Barlem, E. L. D., Almeida, L. K. D., Tomaschewski-Barlem, J. G., Figueira, A. B., \& Lunardi, V. L. (2015). Estratégias de coping de acadêmicos de enfermagem diante do estresse universitário. Revista Brasileira de Enfermagem, 68(5), 783-90. http://dx. doi.org/10.1590/0034-7167.2015680503i

Hjemdal, O., Friborg, O., Stiles, T. C., Rosenvinge, J. H., \& Martinussen, M. (2006). Resilience predicting psychiatric symptoms: A prospective study of protective factors and their role in adjustment to stressful life events. Clinical Psychology and Psychotherapy, 13, 194-201. https://doi.org/10.1 002/cpp.488

Hjemdal, O., Roazzi, A., Dias, M. G. B. B., Roazzi, M., \& Vikan, A. (2009). Exploring the psychometric properties of the resilience scale for adults in a Brazilian sample. (pp. 120-138). In D. Elizur, \& E.
Yaniv (Orgs.), Facet New Horizons in Theory Construction and Data Analysis (pp. 120-138). Jerusalem: FTA.

Juliano, M. C. C., \& Yunes, M. A. M. (2014). Reflections on the social support network as a mechanism for the protection and promotion of resilience. Ambiente \& Sociedade, 17(3), 135-154. http://dx.doi.org/10.1 590/S1414-753X2014000300009

Leme, V. B. R., Del Prette, Z. A. P., Koller, S. H., \& Del Prette, A. (2016). Social Skills and Biocological Model of Human Development: Analyze and Perspectives. Psicologia \& Sociedade, 28(1), 181193. http://dx.doi.org/10.1590/1807-03102015a op001

Lins, L. F. T., Silva L. G., \& Assis, C. L. (2015). Formação em Psicologia: perfil e expectativas de concluintes do interior do Estado de Rondônia. Gerais: Revista Interinstitucional de Psicologia, 8(1), 49-62.

Lizarraga, S. B., Margossian, S. P., Harris, M. H., Campagna, D. R., Han, A. P., Blevins, S., Mudbhary R., \& Fleming, M. D. (2010). Cdk5rap2 regulates centrosome function and chromosome segregation in neuronal progenitors. Development, 137(11), 19071917. doi: $10.1242 / \operatorname{dev} .040410$

Loureiro S. R., \& Sanches, S. H. B. (2006). Crianças com bom desempenho acadêmico: Dificuldades comportamentais e eventos de vida. In M. Bandeira, Z. Del Prette, \& A. Del Prette (Orgs.), Estudos sobre habilidades sociais e relacionamento interpessoal (pp. 69-83). São Paulo: Casa do Psicólogo.

Masten, A. S. (2014). Global perspectives on resilience in children and youth. Child Development, 85(1), 620. https://doi.org/10.1111/cdev.12205

Montes, J. F., Aceves Lupercio, B. I., \& Reynoso González, Ó. U. (2016). Resilience in university students. A comparative study among different careers. Psicogente, 19(36), 227-239. http://dx.doi.or g/10.17081/psico.19.36.1294

Mourão, L., \& Abbad, G. S. (2016). As lacunas de competências na formação em Psicologia e os riscos para a atuação profissional. (pp. 318-334). In A. B. Soares, L. Mourão, \& M. M. P. E. Da Motta (Orgs.), O Estudante Universitário Brasileiro: Características 
cognitivas, habilidades relacionais e transição para o mercado de trabalho. Curitiba: Appris.

Oguz-Duran, N., \& Yüksel, A. (2010). The effects of coping humour and gender on college adjustment in Turkish freshmen. Education, 130(3), 470-478.

Oliveira, C. T., Carlotto, R, C., Vasconcelos, S. J. L., \& Dias, A. C. G. (2014). Adaptação acadêmica e coping em estudantes universitários brasileiros: uma revisão de literatura. Revista Brasileira de Orientação Profissional, 15(2), 177-186.

Oliveira, C. T. D., Dias, A. C. G., \& Piccoloto, N. M. (2013). Contribuições da terapia cognitivocomportamental para as dificuldades de adaptação acadêmica. Revista Brasileira de Terapias Cognitivas, 9(1), 10-18. http://dx.doi.org/10.5935/ 1808-5687.20130003

Pasqualotto, R. A., \& Löhr, S. S. (2015). Habilidades sociais e resiliência em futuros professores. Psicologia Argumento, 33(80), 310-320. doi: 10.7213/psicol. argum.33.080.AO07

Pereira, A. S., Wagner, M. F., \& Oliveira, M. D. S. (2014). Déficits em habilidades sociais e ansiedade social: avaliação de estudantes de psicologia. Psicologia da Educação, (38), 113-122.

Ramos, S. I. V., \& Carvalho, A. J. R. (2007). Nível de stress e estratégias de coping dos estudantes do $1^{\circ}$ ano do ensino universitário de Coimbra. Portal dos Psicólogos. Retrieved from http://www.psicologia. com.pt
Ribeiro, D. C., \& Bolsoni-Silva, A. T. (2011). Potencialidades e dificuldades interpessoais de universitários: estudo de caracterização. Acta Comportamentalia, 19(2), 205-224.

Seidl, E. M. F., Tróccoli, B. T., \& Zannon, C. M. L. C. (2001). Análise fatorial de uma medida de estratégias de enfrentamento. Psicologia: teoria e pesquisa, 17(3), 225-234.

Soares, A. B., \& Prette, Z. A. P. D. (2015). Habilidades sociais e adaptação à universidade: Convergências e divergências dos construtos. Análise Psicológica, 33(2), 139-151. http://dx.doi.org/10.14417/ap.911

Tavares, W. M., Couto, G., \& Silva, R. L. F. C. (2012). Perfil de relações interpessoais e habilidades sociais de estudantes de Psicologia. Estudos Interdisciplinares em Psicologia, 3(1), 75-92.

Vitaliano, P. P., Russo, J., Carr, J. E., Maiuro, R. D., \& Becker, J. (1985). The ways of coping checklist: Revision and psychometric properties. Multivariate behavioral research, 20(1), 3-26.

Yamamoto, O. H., da Rocha Falcão, J. T., \& de Sousa Seixas, P. (2011). Quem é o estudante de psicologia do Brasil? Avaliaçao Psicologica: Interamerican Journal of Psychological Assessment, 10(3), 209232.

Yamamoto, O. H., \& Oliveira, I. F. (2010). Política Social e Psicologia: Uma trajetória de 25 anos. Psicologia: Teoria e Pesquisa, 26(spe), 9-24. doi: 10.1590/ S0102-37722010000500002

\section{Zeimara de Almeida Santos}

Universidade Salgado de Oliveira

Doctorado y Maestro en Psicología Social en la línea de investigación Desarrollo Socio-cognitivo, Relaciones Interpersonales y Educación por la Universidade Salgado de Oliveira. La línea de investigación se centra en temas relacionados con las relaciones interpersonales, las habilidades y la competencia social, el entrenamiento en habilidades sociales.

ORCID: 0000-0001-8674-8738

Autor corresponsal: zeimaradealmeida@gmail.com

Adriana Benevides Soares

Universidade Estadual do Rio de Janeiro e Universidade Salgado de Oliveira

Post-doctoral realizado en la Universidad Federal de São Carlos (2011), Maestría en Psicología Cognitiva por la Universidad de París XI (1990), doctorado en Psicología Cognitiva por la Universidad de París XI (1995). Posee experiencia de docencia e investigación en las áreas de psicología de la memoria y del aprendizaje, psicología de las relaciones interpersonales y metodología de la investigación.

ORCID: 0000-0003-2892-1808

adribenevides@gmail.com 